\section{Field Performance Comparison of Two Transgenic Summer Squash Hybrids to Their Parental Hybrid Line}

\author{
Juan Pablo Arce-Ochoa ${ }^{1}$, Frank Dainello ${ }^{2}$, and Leonard M. Pike ${ }^{3}$ \\ Department of Horticultural Sciences, Texas A\&M University, College Station, \\ TX 77843-2133
}

\author{
David Drews ${ }^{4}$ \\ Asgrow Seed Company, P.O. Box 720094, McAllen, TX 78504
}

Additional index words. squash, Cucurbita pepo, biotechnology, virus resistance

\begin{abstract}
Pavo', a commercially grown, virus-susceptible squash (Cucurbita pepo L.) hybrid, and two experimental virus-resistant transgenic squash hybrids, XPH-1719 and XPH-1739, were tested for field performance. The two transgenic squash hybrids possess the desired fruit and plant characteristics of their parental line, 'Pavo', plus resistance to zucchini yellow mosaic virus and watermelon mosaic virus 2 (XPH-1719), and resistance to zucchini yellow mosaic virus, watermelon mosaic virus 2 , and cucumber mosaic virus (XPH-1739). Percent emergence and days to flowering were similar among the three hybrids. XPH-1719 and XPH-1739 were equally effective in producing a high percentage of quality marketable fruit and yields with $90 \%$ and $13,800 \mathrm{~kg}^{-h a^{-1}}$ and $87 \%$ and 16,500 kg.ha $^{-1}$, respectively. XPH-1719 and XPH-1739 demonstrated their outstanding virus resistance over 'Pavo' by producing only $3 \%$ and $14 \%$ symptomatic plants, respectively, compared to $53 \%$ for 'Pavo'. They also produced the lowest percentage of infected fruit, $0 \%$ and $7 \%$, respectively, with 'Pavo' at $26 \%$.
\end{abstract}

Biotechnology is being used as an extension of conventional plant breeding, particularly when conventional methods cannot solve a particular problem (Oliver and Giblin, 1992). A major objective of cucurbit breeders using biotechnology techniques is to develop resistance to the four aphid-transmitted viruses that affect cucurbits. Chemical control has provided little or no positive results in controlling the aphids before they spread the viruses (Oliver and Giblin, 1992). The viruses of primary concern are cucumber mosaic virus (CMV), watermelon mosaic virus 2 (WMV2), zucchini yellow mosaic virus (ZYMV), and papaya ringspot virus (PRV) (Oliver and Giblin, 1992). Virus symptoms are most severe when plants are infected during their seedling stage. Economic loss from plant injury and fruit distortion and discoloration may result from severe infection occurring at any stage of plant growth (Sherf and Macnab, 1986).

Although resistance to viruses is expressed in some wild species of cucurbits (Provvidenti,

Received for publication 22 July 1994. Accepted for publication 14 Feb. 1995. Use of trade names does not imply endorsement of the products named nor criticism of similar ones not named. Asgrow Seed Co. is gratefully acknowledged for providing seed and financial assistance to fund this research project. The cost of publishing this paper was defrayed in part by the payment of page charges. Under postal regulations, this paper therefore must be hereby marked advertisement solely to indicate this fact. ${ }^{1}$ Graduate Student.

${ }^{2}$ Extension Vegetable Specialist.

${ }^{3}$ Director, Vegetable Improvement Center.

${ }^{4}$ Technical Services Regional Manager, Texas and Mexico.
Two experimental virus-resistant transgenic hybrids developed by the Asgrow Seed Co., Kalamazoo, Mich., XPH-1719 and XPH1739 , and a commercially grown virus-susceptible hybrid, 'Pavo', were tested at the Texas A\&M Univ. Experimental Farm near College Station in Summer 1993. The two transgenic squash hybrids possess the desired fruit and plant characteristics of their parental line, 'Pavo', plus resistance to ZYMV and WMV2 (XPH-1719) and resistance to ZYMV, WMV2, and CMV (XPH-1739). The experiment used $1625 \mathrm{~m}^{2}$ of land, including a $9.1-\mathrm{m}-$ wide required buffer zone surrounding the experimental area. The three hybrids were evaluated using a randomized block design with three replications. Experimental plots were $15.2 \mathrm{~m}$ long with rows $1.0 \mathrm{~m}$ apart. Each replication was separated by a 1.5 -m-wide alleyway. Plots were established by handplanting one seed every $0.3 \mathrm{~m}$ in a single row per bed. Plants were grown on drip-irrigated, 1.0-m-wide beds mulched with black plastic. The buffer rows were all planted with 'Pavo', the susceptible hybrid. All other cultural practices were conducted as recommended in Dainello (1993) and Swiader et al. (1992). Due to the limited availability of seed, the initial populations of XPH-1719, 'Pavo', and XPH-1739 were unequal, i.e., 50, 50, and 33 plants/plot, respectively. Therefore, 'Dixie', another virus-susceptible hybrid, was used as fill to balance the XPH-1739 plots.

All hybrids were indexed for seedling emergence rate, days to flower, total yield, and virus infection. Plots were harvested every other day for 2 weeks for a total of seven harvests. Before each harvest, all plants that looked infected were flagged for easy detection and counted to determine infection severity visually. Number of infected and noninfected fruit, determined visually, and their corresponding fresh weights were recorded. Fruit showing other problems also were counted and weighed in every harvest. All fruit were bagged and properly disposed of after each harvest as requested by the proprietors of the three hybrids. Data were subjected to analysis of variance, and the mean responses of the descriptors were compared using Duncan's multiple range test at $P \leq 0.05$.

\section{Results and Discussion} availability of the crop for consumers.

The purpose of this trial was to compare the field performance of two experimental transgenic squash hybrids and their parental line, a virus-susceptible summer squash hybrid. 1719 and XPH-1739 outperformed their virus-susceptible parental line 'Pavo' for most of the variables tested. Few differences in

Table 1. Mean percent infected and total number of plants per hectare and mean percent virus-infected fruit and yield of three squash hybrids from seven harvest counts. College Station, Texas, 1993.

\begin{tabular}{|c|c|c|c|c|}
\hline \multirow[b]{2}{*}{ Hybrid } & \multirow{2}{*}{$\begin{array}{l}\text { Virus-infected } \\
\text { plants } \\
(\%)\end{array}$} & \multirow{2}{*}{$\begin{array}{c}\text { No. } \\
\text { plants/ha } \\
(1000 \mathrm{~s})\end{array}$} & \multicolumn{2}{|c|}{$\begin{array}{l}\text { Virus-infected } \\
\text { fruit }\end{array}$} \\
\hline & & & $(\%)$ & $\mathrm{kg} \cdot \mathrm{ha}^{-1}(1000 \mathrm{~s})$ \\
\hline Pavo & $53 \mathrm{a}^{\mathrm{z}}$ & 25.8 & $26 \mathrm{a}$ & $4.55 \mathrm{a}$ \\
\hline XPH-1719 & $3 \mathrm{~b}$ & 30.1 & $0 \mathrm{~b}$ & $0 \mathrm{~b}$ \\
\hline XPH-1739 & $14 \mathrm{~b}$ & 31.7 & $7 \mathrm{~b}$ & $1.10 \mathrm{ab}$ \\
\hline
\end{tabular}

${ }^{2}$ Mean separation in columns by Duncan's multiple range test, $P \leq 0.05$. 
Table 2. Analysis of variance (ANOVA) corresponding to the virus-infected yield data of three squash hybrids from seven harvest counts.

\begin{tabular}{|c|c|c|c|c|c|c|c|c|}
\hline Source & $R^{2 \mathrm{y}}$ & $\mathrm{CV}$ & df & $\begin{array}{l}\text { Sum of } \\
\text { squares }\end{array}$ & $\begin{array}{l}\text { Mean } \\
\text { square }\end{array}$ & F value & $P>\mathrm{F}$ & $\begin{array}{l}\mathrm{VIY}^{\mathrm{z}} \\
\text { mean }\end{array}$ \\
\hline Model & & & 4 & 45454425 & 11363606 & 3.77 & 0.1135 & \\
\hline Error & & & 4 & 12058974 & 3014743 & & & \\
\hline \multirow[t]{2}{*}{ Corrected total } & & & 8 & 57513399 & & & & \\
\hline & 0.790328 & 92.62641 & & & $1736.3017^{\mathrm{x}}$ & 1.91 & & 1874.5211 \\
\hline Replication & & & 2 & $11499310^{\mathrm{w}}$ & 5749655 & 1.91 & 0.2620 & \\
\hline Hybrid & & & 2 & $33955114^{w}$ & 16977557 & 5.63 & 0.0687 & \\
\hline
\end{tabular}

zVirus-infected yield.

${ }^{y} R^{2}=$ coefficient of determination .

${ }^{x}$ Root mean square error.

${ }^{w}$ ANOVA sum of squares.

performance were noted between the two genetically engineered hybrids.

Percent seedling emergence and flowering were similar among the three hybrids. Two weeks after planting, a series of high winds broke and killed several plants; as a result, data were collected from the first $6 \mathrm{~m}$ of every experimental plot. More than half of the 'Pavo' plants were virus-infected, 18 times as many as for XPH-1719 (Table 1). We assume that the stunted growth and leaf malformation shown by plants of the susceptible hybrid infected with the viruses affected their flower production. The high levels of infection found in these plots can be attributed to the presence of large populations of aphids that presumably transmitted the viruses from plant to plant. XPH-1719 and XPH-1739 had a far lower percentage of infected fruit than 'Pavo' (Table 1). Even though the transgenic plants presumably were infected by aphids, their genetic resistance helped them to reduce viral replication. The virus symptoms expressed by the transgenic hybrids were determined by an enzyme-linked immunosorbent assay analysis to be those of the papaya ringspot virus, which also attacks squash. Due to the high summer temperatures, all hybrids produced a few double fruit, accounting for most of the cull fruit; however, differences in the quantity of cull fruit among hybrids were not significant. XPH-1719 produced a lower virus-infected fruit yield than 'Pavo' (Tables 1 and 2). $\mathrm{XPH}-1719$ and XPH-1739 were equally effective in producing a high percentage of quality marketable fruit and yields, with $90 \%$ and $13,800 \mathrm{~kg} \cdot \mathrm{ha}^{-1}$ and $87 \%$ and $16,500 \mathrm{~kg} \cdot \mathrm{ha}^{-1}$, respectively. This 3000 plus $\mathrm{kg} \cdot \mathrm{ha}^{-1}$ relative difference in marketable yield between the lines may well represent an economic yield increase to the growers.

The two transgenic squash hybrids XPH1719 and XPH-1739 demonstrated an increased virus resistance over 'Pavo' by producing a smaller percentage of symptomatic plants and a lower percentage of infected fruit.
Given that XPH-1719 and XPH-1739 were equally effective in producing high-quality marketable fruit and marketable yields, it is the grower's option to select from among the two hybrids the one that works best for their climatic and soil conditions.

\section{Literature Cited}

Dainello, F.J. 1994. Commercial vegetable production guide. Texas Agr. Ext. Serv., Texas A\&M Univ., College Station.

Oliver, T. and B. Giblin. 1992. How Asgrow uses biotechnology to solve plant breeding problems. Asgrow News. Asgrow SeedCo., Kalamazoo, Mich.

Provvidenti, R. 1993. Resistance to viral diseases of cucurbits, p. 8-43. In: M. Kyle (ed.). Resistance to viral diseases of vegetables. Timber Press, Portland, Ore.

Sherf, A.F. and A.A. Macnab. 1986. Vegetable diseases and their control. 2nd ed. WileyInterscience Publ., New York.

Swiader, J.M., G.W. Ware, and J.P. McCollum. 1992. Producing vegetable crops. 4th ed. Interstate Publishers, Danville, Ill. 